\title{
The Effects of Gymnastics Training Combined With Music in Children with Autism Spectrum Disorder and Down Syndrome
}

\author{
Betül Akyol $^{1} \&$ Songül Pektaş ${ }^{2}$ \\ ${ }^{1}$ Faculty of Sport Sciences, Inonu University, Malatya, Turkey \\ ${ }^{2}$ Faculty of Education, Amasya University, Amasya, Turkey \\ Correspondence: Betül Akyol, Faculty of Sport Sciences Inonu University, Malatya, Turkey. Tel: \\ 90-422-377-3000. E-mail: betul.akyol@inonu.edu.tr
}

\author{
Received: July 9, $2018 \quad$ Accepted: August 21, $2018 \quad$ Online Published: October 22, 2018 \\ doi:10.5539/ies.v11n11p46 URL: https://doi.org/10.5539/ies.v11n11p46
}

\begin{abstract}
The aim of this study was to evaluate the effects of gymnastics training combined with music on balance, loco-motor level and coordination in children with autism spectrum disorder (ASD) and down syndrome (DS). This randomized, controlled experimental trial included 30 children (15 children with DS, 15 children with ASD) aged 8 to 14 years. The children were separated into 2 groups, as Group 1 in which ASD and Group 2 in which DS treated gymnastics training with music for 16 weeks, 2 days a week, 1.5-2 hours. Flamingo balance test, functional reach test, Wall Catch coordination test and flexibility test were used to evaluate balance, dynamic balance, loco-motor level and coordination, flexibility, respectively. All groups were evaluated before training and at the end of 16 weeks. When the pre-training and post-training parameters were compared between the groups, a increase was determined in the parameters of balance, loco-motor level and coordination, flexibility in Group1. This increase was statistically greater in Group 1. Statistically significant difference was determined in Group 2 with respect to functional reach test, sit and reach test values. No statistically significant difference was determined in Group 2 in respect of Flamingo and Wall Catch coordination tests. As a result; gymnastics training combined with music were found to be effective in increase balance score, improving loco-motor level, coordination, flexibility in children with DS and ASD. The results of this study can be considered to provide important contributions to the understanding and treatment of children with autism and down syndrome.
\end{abstract}

Keywords: gymnastic, music, balance, autism, down syndrome

\section{Introduction}

The autism spectrum (AS) is defined as a "developmental disorder" with unconscious behaviour such as ekolalia (Kircaali-İftar, 2005).

Down syndrome (DS) results from trisomy of chromosome 21 and is connected with a number of deleterious phenotypes, including mental retardation, learning disability, the balance and coordination problems, restriction of motor skills, heart defects and childhood leukaemia, as well as abnormal craniofacial abnormalities, hypotonia and cognitive impairment (Kuzucu, Vidinlisan, Kibar, Ekici, Alpan, \& Çakır, 2008). In addition, clenching of teeth constitutes one of the most significant parafunctional activities of the brain mechanism (Bruininks \& Chavat, 1990).

Experts still do not know how to provide physical activity combined with music physically or treat it effectively (Hendry \& Kerr, 1983). Muscle weakness and joint immobility in children with mental retardation lead to birth defects and difficulties in reaching normal motor development stages (Savucu \& Bicer, 2009).

The treatment of autism and down syndrome usually includes physical activity which is important in improving motoric performance in children with disabilities (Chıvu, 2015). Physical activities include human activities of systematic and conscious practice of the physical exercise, as well as improving the physical development, improving motor capacity, motor skills (Bruininks \& Chavat, 1990). Physical therapy programs increase flexibility and range of motion, improving muscle strength, postural control, balance and coordination system, fine and gross motor skills, brain plastisty and aerobic capacity (Ilınca, Rosulescu, Cosma, \& Rusu, 2015).

Music events offer educational environments for children both entertained and learned. For this reason, it is stated that activities supporting children's development areas using music events can be presented to children (Güler, 
2008).

Gymnastics training is administered rhythmic and remarkable in children with ASD and DS. All the muscle groups are stimulated with pivot points of lower, upper extremity and eye (Fernhall, Miller, \& Tymeson, 1990). The objective is to release movement on the trigger muscles by providing stimulation with exercises. Gymnastics training combined with music include balance and coordination, postural control exercises such as body rotation, functional reach control (Dichter, Darbee, Effgen, \& Palisano, 1993). In order to stimulate erector spina, abdominal and pectoral muscle, exercises and music should be harmonised (Croce, Pitetti, Horvat, \& Miller, 1996).

Since rehabilitation provides postural control and functionality, it has an important place in children with autism and down syndrome with time and cost advantages (Sharav \& Bowman, 1992). The purpose of this study is to investigate the effects of gymnastic training combined with music on balance, loco-motor level and coordination in children with ASD and DS.

\section{Methods}

This randomized, controlled, clinical trial was performed in compliance with the principles of the Declaration of Helsinki. Informed consent was obtained from all the study participants. The target population of the study consisted of children who had been diagnosed with ASD and DS, between April 2017 and July 2018 in the sports hall of the Provincial Directorate of Youth and Sports in Malatya. Individuals that met the inclusion criteria were selected from the target population using probable simple random sampling.

As part of the simple random sampling method, individuals were listed by number and those to be sampled were selected using a random number table. The study included 30 children with autism and down syndrome 15 autism (aged 9-14 years), 15 down syndrome (aged 8-13 years) with the aim of determining the effect of gymnastic activity on the balance, locomotive level and coordination. Children who agreed to participate in the study and met the inclusion criteria were selected by a randomized sampling method in the relevant phase. The inclusion criteria were a diagnosis of autism and down syndrome, children with autism (age 9-14 years) and children with down syndrome (age 8-13 years), retardation of normal motor capacity, and of a sufficient mental capability to be able to adapt to the training program.

Children were excluded from the study if they were outside the age range of 9-14 years (for autism) and the age range of 8-13 years for down syndrome, had any existing health problem, did not allow mental evaluations, did not adapt to the training program, or were not willing to participate in the study. After the application of these criteria, a total of children were excluded.

Following the collection of data and individual pretesting, Gymnastics activities combined with music (a non-verbal violin work called "Beyity Gity" with a $3 / 4$ waltz rhythm pattern belonging to violin virtuoso Farid Farjad) were administered for 16 weeks, followed by 2 days a week, 1.5-2 hours under educator control. The reasons of chosen this music; children can be more easily focused on the rhythm of the song because it can be accompanied by synchronized music training with music and at the same time it is a non-verbal music.

Gymnastics activities consist from front-to-back oscillation with music rhythm, stretching the back and leg muscles on the mat, movement of the lateral flexion, rotation, trampoline movement, one-step start and two-step fall, pull-up movement on sitting position, walking, running, stretching, jumping, sit-up, stand on one foot, walking on the balance board, jumping on the trampoline, reaching forwards and getting balls, throwing the ball, catch the ball, slalom, lifting arms and legs in crawling position on the mat, (unilateral, diagonal, reciprocal), right-left, front-back oscillations sitting on the exercise ball.

The level of static balance was evaluated using a Flamingo Balance test. Child stands on one leg on a metal beam and recording the number of unable to hold balance in $1 \mathrm{~min}$. The Flamingo Balance test scale is important and recommended for evaluation of static balance because of highly reliability (Monyeki, Koppes, Kemper, Monyeki, Toriola, Pienaar \& Twisk, 2005).

The Sit and Reach test is a scale assessing the restriction of flexibility (specifically hamstring and lower back flexibility). The Children with autism or down syndrome sit on the floor with shoes on, and extended one leg so that the sole of the foot was flat against the end of the box. Children then extend her arms forward, bilaterally hands on top and reach forward sling hands along the measuring scale as far as possible without bending the knee of the extended leg. This test repeated three times and better score recorded (Monyeki et al., 2005).

Functional Reach test is used to evaluate the dynamic balance. The child is instructed to next, but not touching and stepping, a wall and position the dominant arm that is closer to the wall at 90 degrees of shoulder flexion with a closed fist. Score of the starting position at the 3rd metacarpal head on the yardstick is recorded. Educator says 
"Reach as far as you can forward without taking a step." The location of the 3rd metacarpal is recorded. Then reached distance recorded in centimetres $(\mathrm{cm})$. Three trials are done and the average of the last two is noted (Fil \& Armutlu, 2014).

Wall Catch Coordination Test is used to evaluate the coordination. The participant stands in a 3-meter distance to the wall. The ball is thrown constantly with the shoulder being fixed with one hand. After a certain number of tests, the other hand is tested. Scoring of successful shoots is done in the same way in both hands. To assess the results, the participant's preferred score should be recorded. Tennis or baseball ball can be used for testing (Aslan, Özer \& Dalkıran, 2016).

Evaluation was made of all the children before training, then at the end of 16 weeks using Flamingo Balance, The Sit and Reach, Functional Reach and Wall Catch Coordination Test.

\section{Data Analyses}

Data obtained in the study were analysed using IBM-SPSS Statistics 22.0 software. The level of balance and flexibility was assessed pre and post treatment using the Dependent $t$ test and between the groups with the Independent $t$ test. Results of the measured values were stated as mean \pm standard deviation. In the power analysis performed, assuming that the difference between pre-treatment and post-treatment balance was 1 unit with $\alpha=$ 0.05 and $1-\beta$ (power) $=0.80$, at least 30 children were required for the sample. The Mann-Whitney $U$ test was used for the comparison of the significance of data that did not meet parametric conditions. A value of $p<0.05$ was accepted as statistically significant.

\section{Results}

Evaluation was made of 30 children with autism or down syndrome, 15 children with a mean age of DS (8.02 \pm 4.32), 15 children with a mean age of ASD $(9.12 \pm 4.23)$. According to pre-test results of ASD and DS; There was no statistically significant difference between groups in flamingo, functional reach test, and Wall Catch coordination test values $(\mathrm{p}>0.05)$. Significant differences were observed in the values of the Sit and Reach Test $(\mathrm{p}<0.05)$ (Table 1).

According to the final test results of ASD and DS; Statistically significant differences were observed in flamingo, functional reach test, Wall Catch coordination test, and Sit and reach test values in the groups $(\mathrm{p}<0.05)$ (Table 2).

Statistically significant differences were observed in diagnosed Autism Spectrum Disorder in respect of flamingo, functional reach test, Wall Catch coordination test, and Sit and reach test values in the pre-test and post-test comparisons $(\mathrm{p}<0.05)$ (Table 3$)$.

There was observed statistically significant difference in diagnosed Down syndrome between pre-test and post-test group in respect of functional reach test, Sit and reach test values $(\mathrm{p}<0.05)$. There were no significant differences in flamingo and Wall Catch coordination tests ( $p>0.05$ ) (Table 4).

At the end of gymnastics training; in group comparison there was a statistically significant difference in the values flamingo (ASD: $6.03 \pm 2.05$, DS: $8.14 \pm 1.03$ ), functional reach test (ASD: $23.03 \pm 1.03$ DS: $16.11 \pm 2.36$ ), Wall Catch coordination test (ASD: $13.03 \pm 1.18$, DS: $8.06 \pm 2.12$ ), Sit and reach test (ASD: $19.11 \pm 1.14$, DS: $17.05 \pm 1.16$ ) $(\mathrm{p}<0.05)$.

At the end of gymnastics training; The ASD group tended to fall less than the DS group. The development of static balance in the ASD group was more than that of the DS group. In the ASD group dynamic balance development, the coordination and flexibility values was better than the DS group. 
Table 1. Pre-test results of diagnosed autism spectrum disorder and down syndrome groups

\begin{tabular}{cccccc}
\hline Tests & & $\mathrm{n}$ & Mean \pm S.d & independent t test & $\mathrm{p}$ \\
\hline \multirow{2}{*}{ Flamingo } & ASD & 15 & $10.03 \pm 2.12$ & -4.112 & 0.221 \\
& DS & 15 & $9.12 \pm 2.03$ & & \\
FRT & ASD & 15 & $12.03 \pm 1.12$ & -3.654 & 0.365 \\
& DS & 15 & $11.13 \pm 1.56$ & & \\
WCC & ASD & 15 & $6.32 \pm 2.08$ & 2.111 & 0.465 \\
& DS & 15 & $6.12 \pm 3.02$ & & \\
Sit and reach & ASD & 15 & $9.21 \pm 2.34$ & \multirow{2}{*}{5.123} & $0.002 *$ \\
\hline
\end{tabular}

*: $\mathrm{p}<0.05$, S.d: Standard deviation, FRT: Functional reach test, W.C.C: Wall Catch Coordination Test, ASD: Autism spectrum disorder, DS: Down syndrome.

Table 2. Post-test results of diagnosed autism spectrum disorder and down syndrome groups

\begin{tabular}{cccccc}
\hline Tests & & $\mathrm{n}$ & Mean \pm S.d & independent t test & $\mathrm{p}$ \\
\hline \multirow{2}{*}{ Flamingo } & ASD & 15 & $6.03 \pm 2.05$ & 3.122 & $0.003^{*}$ \\
& DS & 15 & $8.14 \pm 1.03$ & & \\
\multirow{2}{*}{ FRT } & ASD & 15 & $23.03 \pm 1.03$ & -7.654 & $0.001^{*}$ \\
& DS & 15 & $16.11 \pm 2.36$ & & \\
\multirow{2}{*}{ WCC } & ASD & 15 & $13.03 \pm 1.18$ & -3.213 & $0.002^{*}$ \\
& DS & 15 & $8.06 \pm 2.12$ & & \\
Sit and reach & ASD & 15 & $19.11 \pm 1.14$ & -1.123 & $0.004^{*}$ \\
& DS & 15 & $17.05 \pm 1.16$ & &
\end{tabular}

*: $\mathrm{p}<0.05$, S.d: Standard deviation, FRT: Functional reach test, W.C.C: Wall Catch Coordination Test, ASD: autism spectrum disorder, DS: Down syndrome.

Table 3. Pre-test and post test results of diagnosed autism spectrum disorder

\begin{tabular}{|c|c|c|c|c|c|}
\hline \multicolumn{2}{|c|}{ Tests for ASD } & $\mathrm{n}$ & Mean \pm S.d & independent $t$ test & $\mathrm{p}$ \\
\hline Flamingo & $\begin{array}{l}\text { pre test } \\
\text { post test }\end{array}$ & 15 & $\begin{array}{c}10.03 \pm 2.12 \\
6.03 \pm 2.05\end{array}$ & -4.112 & $0.001 *$ \\
\hline FRT & $\begin{array}{l}\text { pre test } \\
\text { post test }\end{array}$ & 15 & $\begin{array}{l}12.03 \pm 1.12 \\
23.03 \pm 1.03\end{array}$ & 3.654 & $0.001 *$ \\
\hline WCC & $\begin{array}{l}\text { pre test } \\
\text { post test }\end{array}$ & 15 & $\begin{array}{c}6.32 \pm 2.08 \\
13.03 \pm 1.18\end{array}$ & 2.111 & $0.001 *$ \\
\hline Sit and reach & $\begin{array}{l}\text { pre test } \\
\text { post test }\end{array}$ & 15 & $\begin{array}{c}9.21 \pm 2.34 \\
19.11 \pm 1.14\end{array}$ & 5.123 & $0.001 *$ \\
\hline
\end{tabular}

*: $\mathrm{p}<0.05$, S.d: Standard deviation, FRT: Functional reach test, W.C.C: Wall Catch Coordination Test, ASD: autism spectrum disorder.

Table 4. Pre-test and post test results of diagnosed down syndrome groups

\begin{tabular}{llllll}
\hline Tests for DS & & $\mathrm{n}$ & Mean \pm S.d & independent t test & $\mathrm{p}$ \\
\hline \multirow{2}{*}{ Flamingo } & pre test & 15 & $9.12 \pm 2.03$ & & \\
& post test & 15 & $8.14 \pm 1.03$ & -1.001 & 0.321 \\
\multirow{2}{*}{ FRT } & pre test & 15 & $11.13 \pm 1.56$ & 3.712 & \\
& post test & 15 & $16.11 \pm 2.36$ & & $0.003^{*}$ \\
\multirow{2}{*}{ WCC } & pre test & 15 & $6.12 \pm 3.02$ & 1.101 & \\
& post test & 15 & $8.06 \pm 2.12$ & & 0.211 \\
\multirow{2}{*}{ Sit and reach } & pre test & 15 & $12.01 \pm 1.36$ & 3.122 & $0.004^{*}$ \\
& post test & 15 & $17.05 \pm 1.16$ & & \\
\hline
\end{tabular}

*: $\mathrm{p}<0.05$, S.d: Standard deviation, FRT: Functional reach test, W.C.C: Wall Catch Coordination Test, DS: Down syndrome. 


\section{Discussion}

This study investigated the effects of gymnastics movements on balance, loco-motor level and coordination in children with autism spectrum disorder (ASD) and down syndrome (DS) children. The results demonstrated that gymnastic activities combined with music on balance, coordination and flexibility were more effective. This is the first study to compare the effects on balance, locomotive level and coordination of gymnastic activities combined with music used in the rehabilitation of autism and down syndrome.

In comparison of the two groups, it was observed that gymnastics training combined with music was more effective in the development of static and dynamic balance, coordination and flexibility values in children with ASD than in children with DS. Static balance, dynamic balance, coordination and flexibility in children with ASD were more improving than the DS group. Although there was a decrease in flamingo test value according to the results of pre-test and post-test and the values of Wall Catch coordination test increased in the DS group and these values were not statistically significant $(p>0.05)$. The increasing of the functional reach and sit and reach test values was found to be statistically significant $(\mathrm{p}<0.05)$. In the ASD group, the decreasing of the flamingo value, the increasing the Wall Catch coordination test, functional reach and sit and reach test values were found to be statistically significant ( $\mathrm{p}>0.05)$.

Carmeli et al. (2002) investigated the effect of gait band exercises on balance and muscle strength in elderly people with Down syndrome. According to the results of the research, it was stated that there was a statistically significant change in dynamic balance skill levels at the end of the 6 month study period (Carmeli, Kessel, Coleman \& Ayalon, 2002)

Borujeni and colleagues searched the effect of closed kinetic chain training program on the balance skills of mentally retarded individuals, and the results were reported to be statistically significant improvements in both dynamic and static balance values (Borujeni, Ghasemi, Moradi, \& Bakhshi, 2015).

Fotiadou et al. (2009), evaluated the effect of a rhythmic gymnastics program on the dynamic balance ability of a group of adults with intellectual disability. As a result they indicated, the intervention group showed a statistically significant improvement in terms of dynamic balance ability in each interval after the application of the rhythmic gymnastics program compared with the control group (Fotiadou, Neofotistou, Sidiropoulou, Tsimaras, Mandroukas \& Angelopoulou, 2009)

Giagazoglou et al. assessed the effects of a 12-week trampoline exercise intervention program on motor and balance ability of school aged children with intellectual disability. It is signed that trampoline intervention is a significant improvements of participants' performance in all motor and balance tests. In conclusion, trampoline training can be an effective intervention for improving functional outcomes and can be recommended as an alternative model of physical activity programming for improving balance and motor performance (Giagazoglou, Kokaridas, Sidiropoulou, Patsiaouras, Karra, \& Neofotistou, 2013).

In the study conducted the effect of balance training on balance skills of undernourished children was investigated by Mahravan, Papi, and Mosleh (2015), and the results showed that the 8-week study had a positive effect on dynamic and static balance.

The gymnastics training made with music in the study increased the development of static, dynamic balance, coordination and flexibility in children with ASD more than in DS children. Even though children with DS are more flexible, they have difficulties in learning and maintaining their movements, and children with ASD have been found to be more successful at learning and maintaining their movements with effective communication, even though they are not flexible. Nonetheless, gymnastics training combined with music had positive effects in both groups. By increasing attention, motivation and eagerness in children's music-rhythm and movement relation, which is used in this work, it has improved balance, coordination and flexibility parameters.

\section{Conclusion}

In conclusion, this study demonstrated that gymnastic training combined with music effectively improved systatic-dynamic balance, loco-motor level and coordination parameters. In this study, it was observed that gymnastic movements made with music in ASD and DS children were effective on static and dynamic balance, coordination, loco-motor development. As a result of gymnastic traning made with music, static, dynamic balance, coordination and flexibility values improved in both disabled groups.

\section{References}

Aslan, C. S., Özer, U., \& Dalkıran, O. (2016). Kız çocuklarında koordinasyon ve reaksiyon özelliklerinin yaş değişkenine göre incelenmesi. MAKÜ Să̆. Bil. Enst. Derg., 4(1), 27-33. 
Borujeni, B. G., Ghasemi, B., Moradi, M. R., \& Bakhshi, M. (2015). Survey the effect of closed kinetic chain training program on the balance of mentally retarded students. International Journal of Sport Studies, 5(2), 164-167.

Bruininks, R. H., \& Chavat, M. (1990). Research on the motor proficiency of persons with mental retardation, psychomotor therapy and adapted physical activity. In H. V. Coppenolle, \& J. Simons (Eds.), Better Movement Proceeding of the 2 International Symposium (pp. 43-69).

Carmeli, E., Kessel, S., Coleman, R., \& Ayalon, M. (2002). Effects of a treadmill walking program on muscle strength and balance in elderly people with down syndrome. Journal of Gerontology: Medical Sciences, 57A(2), 106-110. https://doi.org/10.1093/gerona/57.2.M106

Chivu, I. D. (2015). The development of the students' motoric capacity through dance. Journal of Sport and Kinetic Movement, 26(2), 64-69.

Croce, R. V., Pitetti, K. H., Horvat, M., \& Miller, J. (1996). Peak torque, average power, and hamstrings/quadriceps ratios in nondisabled adults and adults with mental retardation. Arch Phys Med Rehabil, 77, 369-72. https://doi.org/10.1016/S0003-9993(96)90086-6

Dichter, C. G., Darbee J. C., Effgen, S. K., \& Palisano, R. J. (1993). Assessment of pulmonary function and physical fitness in children with Down syndrome. Pediatr Phys Ther, 5(1), 3-8.

Fernhall, B., Miller, A. L., \& Tymeson, G. T. (1990). Maximal exercise testing of mentally retarded adolescents and adults: Reliability study. Arch Phys Med Rehabil, 71, 1065-1068.

Fil, A., \& Armutlu, K. (2014). Parkinson hastalarında duyu bütünlüğü eğitiminin postüral instabiliteye etkisi. Ergoterapi ve Rehabilitasyon Dergisi, 2(2), 91-104.

Fotiadou, E. G., Neofotistou, K. H., Sidiropoulou, M. P., Tsimaras, V. K., Mandroukas, A. K., \& Angelopoulou, N. A. (2009). The effect of a rhythmic gymnastics program on the dynamic balance ability of individuals with intellectual disability. The Journal of Strength \& Conditioning Research, 23(7), 2102-2106.

Giagazoglou, P., Kokaridas, D., Sidiropoulou, M., Patsiaouras, A., Karra, C., \& Neofotistou, K. (2013). Effects of a trampoline exercise intervention on motor performance and balance ability of children with intellectual disabilities. Research in Developmental Disabilities, 34(9), 2701-2707.

Güler, N. (2008). Müzikle çocuk eğitimi. İstanbul: Hepsi Çocuk Yayınları.

Hendry, J., \& Kerr, R. (1983). Communication through physical activity for learning disabled children. Percept Mot Skills, 56(1), 155-158.

Ilınca, I., Rosulescu, E., Cosma, G., \& Rusu, L. (2015). Effectiveness of aquatic exercises program to improve the level of physical fitness for children with disabilities. Journal of Sport and Kinetic Movement, 26(2), 137-140.

Kırcaali-İftar, G. (2005). Otistik Özellik Gösteren Çocuklara İletişim Becerilerinin Kazandırılması. İstanbul: YA-PA.

Kuzucu, A., Vidinlisan, S., Kibar, A. E., Ekici, F., Alpan, N., \& Çakır, H. T. (2008). Down sendromunda konjenital kalp hastalığı sıklığının ve ekokardiyografik bulguların değerlendirilmesi. Genel Tip Dergisi, 18(3), 105-110.

Mahravan, M., Papi, H., \& Mosleh, Z. (2015). The effect of eight weeks equilibrium exercises on the equilibrium of subnormal children. Walia Journal, 31(4), 236-241.

Monyeki, M. A., Koppes, L. L. J., Kemper, H. C. G., Monyeki, K. D., Toriola, A. L., Pienaar, A. E., \& Twisk, J. W. R. (2005). Body composition and physical fitness of undernourished South African rural primary school children. European Journal of Clinical Nutrition, 59(7), 877-883. http://doi.org/10.1038/sj.ejen.1602153

Savucu, Y., \& Biçer, S. Y. (2009). Zihinsel engellilerde fiziksel aktivitelerin önemi. Türkiye Klinikleri Journal of Sports Sciences, 1(2), 117-122.

Sharav, T., \& Bowman, T. (1992). Dietary practices, physical activity, and body-mass index in a selected population of down syndrome children and their siblings. Clin Pediatr, 31, 341-344. 


\section{Copyrights}

Copyright for this article is retained by the author(s), with first publication rights granted to the journal.

This is an open-access article distributed under the terms and conditions of the Creative Commons Attribution license (http://creativecommons.org/licenses/by/4.0/). 